\title{
DOKTRIN ULT RA VIRES DAN KONSEKUENSI PENERAPANNYA TERHADAP BADAN HUKUM PRIVAT
}

\author{
J ohnny Ibrahim \\ E-mail: john.ibra@yahoo.com
}

\begin{abstract}
An acts is ultra vires when corporation is without authority to perform it under any circumstance or for any purpose beyond the scope of the powers of corporation, as defined by its charter or by law of incorporation. Some countries restrict the application of the doctrine of ultra vires but do not abolish it. Indonesia adopt doctrine of ultra vires in some of its law such as Law No. 40 of 2007 concerning Limited Liability Company and Law No. 25 of 2003 concerning Anti Money Laundering. The provisions of ultra vires doctrine has impact to other legal person than Limited Liability Company.
\end{abstract}

Key words: ultra vires, extra vires, intra vires.

\begin{abstract}
Abstrak
Suatu perbuatan atas nama perusahaan disebut ultra vires apabila dilakukan dengan maksud dan tujuan apapun melampaui kewenangan yang diatur dalam anggaran dasar perusahaan. Beberapa negara mulai membatasi penerapan doktrin ultra vires tetapi tidak mencabutnya sama sekali. Indonesia menerapkan doktrin ultra vires sebagaimana diatur dalam UU No. 40 Tahun 2007 tentang Perseroan Terbatas dan UU No. 25 tahun 2003 tentang Tindak Pidana Pencucin Uang. Pemberlakuan doktrin ultra vires membawa dampak pengaturan yang sama terhadap badan hukum lain selain Perseroan Terbatas.
\end{abstract}

Kata kunci: ultra vires, extra vires, intra vires.

\section{Pendahuluan}

Berbagai pemberitaan yang muncul dimedia, maupun kasus-kasus yang menjadi perhatian masyarakat yang sampai di pengadilan, umumnya melibatkan sengketa tentang penyalahgunaan kewenangan yang dilakukan oleh pihak direksi dalam perusahaan maupun badan hukum privat yang aktif menjalankan kegiatannya di tengah-tengah masyarakat. Praktik penyalahgunaan kewenangan tersebut dapat terjadi oleh karena keterbatasan pemahaman tentang doktrin hukum yang melandasi dan membatasi penyelenggaraan kewenangan yang diberikan perusahaan dan atau badan hukum dalam praktik manajemen dan pengelolaan kegiatannya sehari-hari. Atas dasar pertimbangan tersebut, maka perlu dilakukan kajian hukum untuk memperjelas batas-batas wewenang yang diberikan pada direksi perseroan, atau pengurus badan hukum sebagaimana yang ditetapkan dalam anggaran dasarnya. Untuk itu maka lingkup pembahasan meliputi pemahaman terhadap doktrin terkait yaitu: ultra vires, extra vires dan intra vires.

Badan hukum dapat dibedakan antara badan hukum privat/perdata, dan badan hukum publik. Eksistensi badan hukum privat yang meliputi syarat-syarat pendirian dan pembubaran, kewajiban pendiri dan pengurus serta hak-hak dan kewajiban yang melekat erat padanya, diatur dalam KUH Perdata (Civil Code) dan atau KUH Dagang (Commercial Code) dan melalui penetapan pemerintah dalam undang-undang terkait. Di Indonesia, moderenisasi terhadap aturan-aturan dalam KUH Dagang yang dianggap telah tidak sesuai perkembangan jaman mengakibatkan banyak pengaturan terhadap pendirian badan hukum diatur dalam aturan 
perundang-undangan lain, sehingga menghapus dan atau memberikan pengertian baru terhadap pasal-pasal tertentu dalam KUH Dagang. Sesuai pemahaman klasikal, badan hukum privat atau badan hukum perdata, adalah badan hukum yang didirikan oleh masyarakat dan diakui oleh negara, atau didirikan oleh negara, tetapi tidak memiliki kewenangan menetapkan kebi-jakan publik yang mengikat publik. Beberapa contoh yang dapat dikemukan disini adalah Perseroan Terbatas, Koperasi, Yayasan dan Perkumpulan.

Badan hukum publik didirikan berdasarkan aturan hukum yang khusus mengaturnya baik melalui perundang-undangan ataupun penetapan pemerintah (executive order). Badan hukum publik dengan demikian adalah merupakan badan hukum yang didirikan oleh negara dan memiliki kewenangan menetapkan kebijakan publik yang mengikat umum atau masyarakat untuk mematuhinya. Contohnya adalah negara, pemerintah pusat, propinsi, kabupaten dan kota. Peraturan-peraturan yang dikeluarkan oleh badan hukum publik mengikat untuk dipatuhi oleh siapa yang terkena peraturan tersebut. Tulisan ini membahas penerapan doktrin ultra vires terhadap badan hukum privat khususnya penerapannya dalam perusahaan perseroan dan dampaknya terhadap badan hukum privat lain yang masuk dalam wilayah hukum keperdataan, dan tidak mengulas penerapan doktrin ultra vires dalam penyelenggaraan kekuasaan pemerintahan dalam badan hukum publik yang merupakan wilayah hukum administrasi.

\section{Pembahasan \\ Makna doktrin ultra vires, extra vires dan intra vires}

Ultra vires berasal dari bahasa Latin yang dalam bahasa Inggris diterjemahkan sebagai "beyond the power" atau dalam bahasa Indonesia diterjemahkan melampaui kewenangan. Pemahaman secara akademis misalnya dituliskan oleh Timothy Endicott, "ultra vires means beyond (the agency) legal powers" ${ }^{1}$. Frank Mack mengartikannya sebagai:

"The term ultra vires in its proper sense, denotes some act or transaction on the part of corporation which although not unlawfull or contrary to public policy if done or executed by an individual, is jet beyond the legitimate powers of the corporation as they are defined by the statute under which it is formed, or which are applicable, or by its charter or incorporation papers" ${ }^{2}$.

Ultra vires, dalam kepustakaan hukum, seringkali disebut juga sebagai extra vires, karena extra vires juga memiliki makna yang sama dengan ultra vires yaitu beyond the power atau melampaui kewenangan. Doktrin ultra vires diterapkan pada perusahaan-perusahaan serta organisasi kemasyarakatan, organisasi sosial dan keagamaan berbadan hukum yang memiliki peranan yang sangat luas terhadap kehidupan masyarakat. Sebuah per-buatan yang dilakukan oleh organ perusahaan, pengurus organisasi sosial berbadan hukum, yang dilakukan melampaui kewenangan yang diatur dalam Anggaran Dasar dan atau aturan perudanganundangan terkait yang mengatur eksistensi badan hukum tersebut, maka perbuatan tersebut dapat dikategorikan sebagai tindakan ultra vires atau perbuatan melampaui kewenangan. Dampak pelanggaran terhadap doktrin ultra vires dapat berupa tuntutan perdata yang diajukan oleh pihak-pihak yang dirugikan, serta dapat dimintakan pertanggung jawaban pidana baik terhadap korporasi maupun terhadap organ yang melakukannya.

Doktrin ultra vires sebenarnya telah lama dijadikan pegangan oleh para pemangku kepentingan dalam pengelolaan perusahaan. Pada awalnya doktrin tersebut tidak terlalu diperhatikan karena dianggap tidak bermanfaat dalam memberikan perlindungan hukum terhadap po-

\footnotetext{
Timothy Endicott, "Constitutional Logic", University of Toronto Law J ournal, No. 53, Tahun 2003, hlm. 201

Frank A. Mack, "The Law on Ultra Vires Acts and Contracts of Private Corporations", Marquette Law Review, tersedia di website http://epublications. marquette. edu/ cgi/ viewcontent. cgiarticle $=4163$ diak ses tanggal 23 Mei 2011.
} 
sisi investor dan kreditur. Hal ini dapat dipahami karena dalam bentuk awal perusahaan sebelum revolusi industri melanda Eropa masih bersifat partnership. Segala sesuatu yang bersifat fundamental dalam perusahaan mesti saling diketahui oleh partner usaha atau kongsinya masing-masing. Sekalipun terjadi perubahan yang penting yang telah dilakukan dan belum diketahui partner/kongsi lain dalam perusahaan yang berbentuk partnership tersebut, namun hal itu masih dapat diratifikasi oleh para kongsi lain dalam rapat perusahaan yang diadakan untuk kepentingan tersebut.

Pada tahun 1875 terjadi perubahan yang fundamental di Inggris berkaitan dengan pemahaman dan penerapan doktrin ultra vires, karena doktrin tersebut oleh House of Lords ditetapkan masuk dalam Company Act. Latar belakangnya keputusan House of Lords tersebut adalah diputuskannya kasus Ashbury Railway Carriage and Iron Company Ltd v. Hector Riche (1875) L. R. 7 H.L. 653. Dalam kasus ini, Anggaran Dasar (Memorandum of Association) Ashbury Railway Carriage and Iron Company yang didirikan berdasarkan Company Act, 1862 menyebutkan bahwa perusahaan tersebut berusaha dalam bidang pembuatan dan penjualan, meminjamkan dan atau menyewakan gerbong barang dan gerbong penumpang, serta segala sesuatu yang berkaitan dengan bisnis pembuatan, penjualan, persewaan gerbong. Namun dalam Kenyataannya direksi Ashbury Railway Carriage and Iron Company Ltd. justru membuat kontrak dengan Hector Riche isinya antara lain untuk membiayai pembangunan jaringan rel kereta api di Belgia, yang tidak termasuk dalam apa yang diamanatkan dalam Anggaran Dasar (Memorandum of Association) perusahaan tersebut.

Isu hukum yang muncul dalam kasus Ashbury Railway Carriage and Iron Company Ltd v. Hector Riche adalah apakah kontrak tersebut berlaku atau tidak, dan apakah kontrak dapat diratifikasi oleh para pemegang saham (para kongsi) Ashbury Railway Carriage and Iron Company Ltd ?. Ternyata The House of Lords memutuskan bahwa: (a) The contract was beyond the objects as defined in the objects clause of its memorandum and, therefore it was void, and

(b) The company had no capacity to ratify the contract.

The House of Lords dalam putusannya menyatakan bahwa perbuatan ultra vires dan atau kontrak yang dibuat secara ultra vires dianggap tidak ada (void) karena perusahaan tersebut tidak memiliki kapasitas untuk membuat kontrak dan dengan alasan tersebut dipertanyakan atas dasar apa para pemegang saham meratifikasi kontrak tersebut, karena dengan berbuat itu maka para pemegang saham juga akan melanggar Company Act, 1862.

Lima tahun kemudian dalam kasus Attorney General v. Great Eastern Railway Co. (1880) 5 A.C. 473, The House of Lords menegaskan kembali makna doktrin ultra vires yang ditegakkan dalam kasus Ashbury Railway Carriage and Iron Company Ltd v. Hector Riche yang antara lain memutuskan bahwa doktrin ultra vires: "ought to be reasonable, and not reasonable understood and applied and whatever may fairly be regarded as incidental to, or consequential upon, those things which the legislature has authorized, ought not to be held, by judicial contruction, to be ultra vires". Sesudah putusan kasus Attorney General v. Great Eastern Railway Co. maka selanjutnya pelaksanaan doktrin ultra vires mengalami pencerahan karena sejak itu maka penerapan doktrin ultra vires lebih diperlonggar: "a company incorporated under the Company Act has power to carry out the object set out in the objects clause of its memorandum and also everything that is reasonably necessary to enable it to carry those objects" ${ }^{3}$. Putusan yang menjadi preseden dalam common law tersebut, menegaskan bahwa perusahaan memiliki kewenangan menjalankan apa yang diatur dalam Anggaran Dasar (intra vires), serta melakukan se-

\footnotetext{
Raghvendra Singh Raghuvanshi, 2009, Doctrin of Ultra Vires in Company Law, National Law Institute University, Bhopal, India, hlm. 5. Diakses pada website http:// apjlsg.com/article-aspx?c6b62 diakses tanggal 20 Februari 2011.
} 
gala sesuatu yang mendukung tercapainya tujuan perusahaan.

Pada kasus Attorney General v. Mersey Railway Co. (1907) 1 Ch 81, sebuah perusahaan yang didirikan dalam bidang usaha bisnis perhotelan, membuat kontrak dengan pihak ketiga untuk membeli perabotan furniture, menggaji pelayan untuk merawat omnibus. Tujuan didirikannya perusahaan tersebut sesuai dengan Anggaran Dasar (Memorandum of Association) hanyalah untuk berusaha dibidang perhotelan dan tidak tercantum usaha usaha pembelian perabotan dan menyewa pelayan. Gugatan diajukan oleh Jaksa ke pengadilan untuk memastikan apakah tindakan direksi tersebut termasuk perbuatan ultra vires. Pengadilan ternyata memutuskan bahwa perusahaan yang bergerak dibidang perhotelan dapat melakukan transaski pembelian perabotan, mempekerjakan pelayan dan merawat omnibus untuk mengantar para tamu hotel ke stasiun kereta api, dan karena itu apa yang dilakukan oleh direksi perusahan perhotelan tersebut adalah "reasonably necessary to effectuate the purpose for which the company has been incorporated", karena itu maka perbuatan direski perusahaan perhotelan tersebut tidaklah termasuk sebagai ultra vires tapi masih dalam lingkup intra vires.

Dinamika penerapan doktrin ultra vires di Inggris berdasarkan hukum yang tidak tertulis dan kebiasaan (customary law), dan the law of precedent, terpengaruh oleh wacana penerapan doktrin ultra vires dalam kasus-kasus yang muncul dalam masyarakat. Aturan-aturan yang tidak tertulis cenderung menjadi aturan tertulis sampai memengaruhi wilayah hukum administrasi sehingga David J enkins menegaskan bahwa “... ultra vires doctrine has become a fundamental part of British constitutional practice" $^{4}$.

Diundangkannya European Communities Act 1972, seiring dengan upaya harmonisasi peraturan hukum di Eropa, di Inggris ada upaya untuk mempersempit pemberlakuan doktrin

David J enkins, "From Unwritten to Written: Transformation in the British Common - Law Constitution", Vanderbilt J ournal of Transnational Law, Vol. $36: 863$, Tahun 2003, hlm. 894. ultra vires, karena keluhan berbagai pihak yang menganggap pemberlakuan doktrin ultra vires secara ketat dan kaku dalam bisnis akan membawa dampak yang merugikan. Reformasi untuk mengakhiri penerapan doktrin ultra vires dalam rangka menghadapi globalisasi perdagangan dunia telah diupayakan oleh Departement of Trade and Industry, namun upaya tersebut belum sepenuhnya berhasil dengan diundangkannya Companies Act 1989 yang masih memberikan indikasi dimungkinkannya penerapan doktrin ultra vires ${ }^{5}$. Barulah dalam Companies Act 2006 pendaftaran pendirian perusahaan tidak wajib lagi mencantumkan tujuan perusahaan seperti dapat dibaca dalam pasal 31(1): "Unless a companys articles specifically restrict the objects of the company, its object are unrestricted". Juga dalam Pasal 41 (1) diatur: "In favour a person dealing with a company in good faith, the power of the directors to bind the company, or authorized to do so, is deem to be free of any limitations under the company's constitution". Sehubungan dengan diundangkannya The Companies Acts 2006 tersebut, Gregory Mitchell dan Richard Brent menegaskan bahwa : "The Companies Act 2006 makes it difficult for and English registered company to seek to rely upon the strict English law ultra vires doctrine" ${ }^{6}$. Dengan demikian perkembangan terbaru di Inggris membatasi secara sangat ketat penerapan doktrin ultra vires tersebut.

Pengaturan dalam European Communities Act 1972, yang ditindak lanjuti dengan dikeluarkannya Company Law Directives (Directive 68/151) dalam article 9(1) mengatur: "Acts done by organs of the company shall be binding upon it even if those acts are not within the objects of the company, unless acts exeed the power that law confers or allows to conffered on those organs". Menurut Stephen Griffin, Directives 68/151 tersebut isinya menghapus

\footnotetext{
Paul J. Omar, Power, "Purposes and Objects: The Protracted Demise of the Ultra Vires Rule", Bond Law Review Volume 16, Issue 1, Tahun 2004, p. 110, tersedia di website http://epublications.bond. edu.au/ blr/ vol16/ iss1/4, diakses tanggal 22 Mei 2011.

6 Gregory Mitchell and Richard Brent, "English Law Contracts, Foreign Counterparties and Ultra Vires", Butterworths Journal of International Banking and Financial Law, p. 463, September 2010.
} 
pemberlakuan tindakan ultra vires bagi pihak ketiga yang beritikad baik (in good faith) ${ }^{7}$. Aturan ini mewajibkan negara-negara yang tergabung dalam Uni Eropa (European Union-EU) memiliki aturan hukum yang harmonis, dan karena itu negara-negara anggota EU masih berusaha mencari jalan keluar membatasi penerapan doktrin ultra vires baik melalui proses pem-buatan aturan yang mengikat maupun dalam proses putusan peradilan (legislative and judicial action) $)^{8}$.

Black's Law Dictionary mendefinisikan tentang ultra vires sebagai berikut:

"An act performed without any authority to act on subject. Acts beyond the scope of the powers of corporation, as defined by its charter or laws of state of incorporation. Acts is ultra vires when corporation is without authority to perform it under any circumstance or for any purpose" $^{\prime \prime}$.

sedangkan definisi tentang extra vires dalam Black's Law Dictionary hanya disebutkan beyond the power, yang merujuk pada pengertian yang sama dengan ultra vires ${ }^{10}$.

Berdasarkan definisi tersebut, dapat dilihat bahwa jika ternyata sebuah perusahaan melalui organ perusahaan tersebut melakukan perbuatan diluar kewenangan atau melampaui kewenangan atau cakupan bidang usaha yang ditetapkan dalam Anggaran Dasar perusahaan atau badan hukum yang dimaksud, maka perusahaan tersebut dikategorikan telah melakukan perbuatan yang dimaksud sebagai ultra vires. Dengan demikian doktrin ultra vires menegaskan bahwa perusahaan atau perseroan tidak dapat melakukan kegiatan diluar apa yang diamanatkan dalam Anggaran Dasar perseroan tersebut (intra vires), sebagai contoh, per-

7 Stephen Griffin, 1998, "The Rise and Fall of the Ultra Vires Rule in Corporate Law", Mountbatten J ournal of Legal Studies, J une 1998, p. 19, tersedia diwebsite http :// ssudl. solent. ac. uk/ policies/954/ diakses tanggal 23 Mei 2011.

8 Paul Craig, "The EJC and Ultra Vires Action : A Conceptual Analysis", Common Market Law Review, No. 48, Tahun 2011, hlm. 395-437

9 Henry Campbell Black, 1990, Black's Law Dictionary, St. Paul, Minn., Sixth Edition, West Publishing Co., p. 1522.

$10 \quad$ lbid., hlm. 588. usahaan yang didirikan untuk berusaha dalam bidang pertambangan sesuai amanat yang dicantumkan dalam Anggaran Dasar pendiriannya, ternyata pada saat yang sama berusaha juga dibidang asuransi yang tidak diatur dalam Anggaran Dasarnya, maka perusahaan tersebut telah melakukan perbuatan yang dimaksud dengan ultra vires tersebut. Jika perusahaan tersebut dalam menjalankan usaha asuransinya membuat kontrak dengan pihak lain yang berkaitan dengan bisnis asuransi yang tidak diatur dalam Anggaran Dasarnya, maka penanda tanganan kontrak itu adalah sebuah perbuatan melanggar hukum dengan konsekuensi kontrak itu dianggap tidak ada (void) atau dapat dibatalkan (voidable). Dalam konstruksi civil law kontrak tersebut dapat berdimensi nietig atau vernietigbaar. Penentuan apakah suatu kontrak dianggap tidak ada (voidnietig) atau dapat dibatalkan (voidable-vernietigbaar), hal itu adalah merupakan kewenangan hakim untuk memutuskan, berdasarkan gugatan yang diajukan oleh salah satu pihak yang dirugikan.

Pembahasan doktrin ultra vires, tidak dapat dilepaskan dari doktrin intra vires, yang memiliki makna yang berlawanan dengan ultra vires. Definisi intra vires menurut Black's Law Dictionary adalah "An act is said to be intra vires (within the power) of a person or corporation when it is within the scope of his or its powers of authority. It is the opposite of the ultra vires"11. Berdasarkan hal tersebut, cakupan intra vires adalah semua yang diamanatkan dalam Anggaran Dasar yang memuat maksud dan tujuan serta kegiatan usaha perseroan serta hal-hal yang menjadi pegangan para direksi perseroan dalam menjalankan kegiatan perseroan.

Belakangan ini banyak negara mulai membatasi penerapan doktrin ultra vires dalam hukum bisnis. Di Belanda, pembatasan penerapan doktrin ultra vires dapat dilihat dalam Pasal 36 (h) Buku I Bab 3 tentang Korporasi dari Commercial Code of Netherlands, diatur sebagai berikut:

11 Ibid., hlm. 823. 
"The Corporation cannot invoke the defense that an act performed in its name cannot be helpful to the attaining of the corporation's purpose, unless it show that other party knew that the act was extra vires or that said party could not have been ignorant of the excessions: the other party has no right to invoke excession of the limits of the purpose".

Berdasarkan hal tersebut, penerapan ultra vires atau extra vires di Belanda sudah dibatasi, tidak lagi seluas cakupan penerapan awal doktrin ultra vires dalam hukum perseroan. Perkembangan penerapan hukum di Belanda dengan sistim continental/ civil law, mengikuti apa yang terjadi dalam perkembangan penerapan doktrin ultra vires di negara-negara common law dan Uni Eropa dengan berlakunya European Communities Act 1972. Meskipun masih bersifat dilematis, hal ini terjadi juga di J erman dimana penerapan doktrin ultra vires yang dianggap lebih longgar dalam German Basic Law berhadapan dengan aturan dalam European Law (Europarechts-freundlichkeit) yang harus ditegakkan oleh European Court of J ustice (ECJ) terhadap pembatasan doktrin ultra vires yang semakin ketat $^{12}$.

Hukum perusahaan dan hukum bisnis di Australia, dalam menerapkan doktrin ultra vires hanya dilakukan secara selektif dan esksistensi doktrin tersebut hanya terbatas dalam penerapan secara internal dalam perusahaan, tidak lagi diterapkan pada pihak ketiga diluar perusahaan. Bahkan di Selandia Baru negara tetangga Australia dengan sistem common law muncul wacana bahwa sesungguhnya doktrin ultra vires telah usai dan mati ${ }^{13}$.

Penerapan doktrin ultra vires terhadap kasus-kasus perusahaan di Amerika Serikat, juga mulai menunjukan penurunan. Menurut Robert Hamilton, gejala penurunan kasus-kasus yang melibatkan penerapan doktrin ultra vires

12 Matthias Mahlmann, "The Politics of Constitutional Identity and its Legal Frame - the Ultra Vires Decision of the German Federal Constitution", German Law J ournal, Vol. 11 No. 12, p. 1410 - 1411, Tahun 2010.

13 Philip A. J oseph, "The Demise of ultra vires - a reply to Christoper Forsyth and Linda Whittle", Canterbury Law Review 10, tersedia di website http: // NZLII/ Databases/ canterbury law review/2002/ (2002) CanterLaw Rw 10, diakses tanggal 22 Mei 2011. adalah karena pemberlakuan doktrin lain oleh hakim yang lebih dapat diterima umum seperti misalnya doktrin estoppels, unjust enrichment, quasi contract dan waiver, dalam mengadili kasus-kasus penyalahgunaan kewenangan perusahaan. Hamilton mengulas gejala tersebut sebagai berikut:

\begin{abstract}
"Some courts avoided the ultra vires doctrine by construing purposes clauses broadly and finding implied purpose from the language used. ... Other doctrine that have found acceptance include estoppel, unjust enrichment, quasi contract, and waiver. In particular, these doctrin were applied to ensure that completed transaction would not be disturbed, and to permit tort claimants to recover for injuries suffered as a consequences of the corporation conduct of an ultra vires business. Ultra vires continued to be applied, however, in connection with executor agreements, and when it all is said done, the doctrine was undiserable one, involving harsh and erratic consequences" $^{\prime 14}$.
\end{abstract}

Pernyataan Hamilton tersebut, dapat dilihat bahwa hakim tidak semata-mata mendasarkan keputusannya pada doktrin hukum baku yang ada saja seperti halnya ultra vires tersebut tetapi juga melakukan eksplorasi lebih lanjut dengan melihat kebutuhan yang lebih luas melalui menerapkan doktrin lain yang lebih mencerminkan keadilan dalam memutus perkara. Keseimbangan pertimbangan hakim dalam memutus perkara guna mewujudkan keadilan telah dituliskan jauh sebelumnya oleh Charles E. Carpenter: "The doctrine of ultra vires is the means by which the court have worked out the answer to this question" ${ }^{15}$.

Penerapan doktrin ultra vires, meskipun demikian, secara ketat pada beberapa negara bagian di Amerika Serikat tetap dipertahankan, misalnya di Michigan, praktik hukum yang tidak berijin oleh sebuah korporasi adalah per-

14 Robert W. Hamilton, 2005, Cases and Materials on Corporations, St. Paul. Minn., American Case Book Series, West Group, hlm. 263.

15 Charles E. Carpenter, "Should the Doctrine of Ultra Vires Be Discarded ?". The Yale Law J ournal, Vol. 33, No. 1 (Nov., 1923), tersedia di website http: //www. jstor.org/ pss/ 788458 diakses taggal 22 Mei 2011. 
buatan ultra vires (karena seharusnya mesti dalam bentuk Law Firm), sebagai-mana dikatakan oleh J osh Ard: “... unauthorized practice of law by a corporation a crime. Obviously practicing law would be an ultra vires activity" ${ }^{16}$. Pengawasan secara ketat juga dilakukan pada organisasi-organisasi berbadan hukum yang bersifat non-profit atau bergerak dibidang filantrofis yang memperoleh keringanan dan bahkan penghapusan pajak terhadap donasi yang diberikan pada organisasi-organisasi penghimpun dana tersebut. Statistik menun-jukan bahwa di Amerika Serikat ada sekitar 1.118 .187 organisasi bebas pajak, diantaranya sebanyak 612.830 organisasi nirlaba bebas pajak aktif yang tercantum dalam berkas induk Internal Revenue Service (IRS). Organisasi-organisasi ini tidak hanya bebas pajak, tetapi sumbangan kepada organisasi dimaksud dapat diperhitungkan dalam pengecualian pajak sesuai dengan hukum yang berlaku. Selain itu donasi yang dilakukan oleh korporasi besar berorientasi laba yang diberikan pada para politikus untuk mencapai tujuan politik tertentu juga dianggap sebagai perbuatan ultra vires, karena menyimpang dari tujuan perusahaan ${ }^{17}$. Sebelumnya di Inggris donasi yang diberikan perusahaan untuk tujuan politik juga dianggap sebagai perbuatan ultra vires. Hal ini ditegaskan oleh K.D. Ewing: “... company political donation must surely be ultra vires because they cannot possibly incidental to achieving or promoting any of the goal of the company"18.

Henry R. Cheeseman, dalam menghadapi penyalahgunaan penerapan doktrin ultra vires, mencoba memberikan jalan keluar:

"An act by a corporation that is beyond its express or implied powers is called ultra vires act. The following remedies are available if an ultra vires act is com-

16 J osh Ard, Staying in Bounds, "Preparing Law Student to Recognize the Unauthorized Practice of Law", Michigan Bar J ournal, J une 2002, hlm. 48.

17 Daniel Lipton, "Corporate Capacity for Crime and Politics : Defining Corporate Personhood at the Turn of the Twentieth Century", Virginia Law Review Vol. 96 : 1911, Tahun 2010, hlm. 1919.

18 K.D. Ewing, "Company Political Donations and the Ultra Vires Rule", Modern Law Review, Vol. 47, Jan. 1984, hlm. 71. mited: Shareholders can sue an injunction to prevent the corporation from engaging in the act; The corporation (or shareholder on behalf of the corporation) can sue the officers or directors who caused the act for damaged; and The attorney general of the state of incorporation can bring an action to enjoin the act or to dissolve the corporation" ${ }^{19}$.

Prakarsa untuk menghadapi efek telah dilakukannya perbuatan ultra vires dalam perusahaan adalah para pemegang saham dan dalam kasus tertentu yang bersifat pidana oleh Jaksa Penuntut, maka dapat dikatakan bahwa penerapan doktrin ultra vires pada dasarnya telah mengalami pergeseran yang fundamental. Pada awalnya orientasi penerapannya penekanan pada pihak luar perusahaan (outsider), sekarang beralih penekanannya pada internal perusahaan. Hal ini nampaknya lebih fair dan adil karena pihak direksi perusahaan yang seharusnya lebih tahu tentang seluk beluk serta tujuan perusahaan, ketimbang pihak luar perusahaan yang datang untuk melakukan hubungan bisnis dengan dasar sebuah itikad baik (in good faith).

\section{Badan hukum dan penerapan doktrin ultra vires}

Badan hukum adalah merupakan terjemahan dari suatu istilah hukum Belanda rechtspersoon, atau persona moralis (Latin), atau legal persons (Inggris). Persona adalah terjemahan dari bahasa Yunani prosopon. Istilah prosopon digunakan oleh Epictetus dan kaum Stoa yang mengacu pada manusia individual dalam kapasitasnya menjalankan peran khusus dalam memaknai kehidupan sebagaimana ditentukan oleh akal universal. Dari penggunaan kaum Stoa tersebut, istilah persona atau pribadi masuk dalam hukum Romawi sebagai persona ficta untuk menun-jukan pelaku kewajiban dan pemegang hak secara hukum. Berdasarkan latar belakang tersebut, munculah istilah-istilah seperti artificial person, juridical person, juristic person dan body corporate

19 Henry R. Cheeseman, 2001, Business Law, New Yersey, Prentice Hall, Upper Saddle River, hlm. 741. 
yang diakui memiliki nama dan hak-hak dan kewajiban, perlindungan dan penghargaan layaknya manusia.

Manusia memperoleh kapasitas hukum (legal capacity) sejak ia dilahirkan, maka di J erman badan hukum yang oleh hukum dianggap sebagai artificial person memperoleh hak hidup sejak ia diakui oleh hukum sebagai sebuah entitas yang berbadan hukum (legal personality), sedangkan di Belanda, yang dimaksud dengan rechtspersoon memiliki banyak kesamaan dengan apa yang dimaksudkan para pakar di Indonesia seperti yang akan dibahas kemudian.

Rechtspersoon sering disandingkan dengan natuurlijkperson yang adalah juga merupakan subyek hukum dan merupakan pendukung hak dan kewajiban. Dalam usaha memudahkan pemahaman terhadap badan hukum, para akhli hukum memberikan beberapa definisi tentang badan hukum sebagai berikut. ${ }^{20} \mathrm{Me}$ nurut R. Subekti: "Badan Hukum pada pokoknya adalah suatu badan atau perkumpulan yang dapat memiliki hak-hak dan melakukan perbuatan seperti seorang manusia, serta memiliki kekayaan sendiri, dapat di gugat atau menggugat di depan hakim". Sedang Rochmat Soemitro mendefinisikannya sebagai: "Badan hukum (rechtspersoon) ialah suatu badan yang dapat mempunyai harta, hak serta kewajiban seperti orang pribadi". Sedangkan menurut Sri Soedewi Maschun Sofwan: "Manusia adalah badan pribadi (manusia tunggal). Selain manusia, dapat juga oleh hukum diberikan kedudukan sebagai badan pribadi kepada wujud lain, disebut badan hukum yaitu perkumpulan dari orang-orang versama-sama mendirikan suatu badan (perhimpunan) dan kumpulan harta kekayaan, yang disisihkan untuk tujuan tertentu (Yayasan) kedua-duanya merupakan badan hukum". Pakar hukum dari Belanda, H. Th. Ch. van Kal dan V.F.M. Den Hartog: "Manusia ialah subyek hukum. Selain manusia, menurut hukum ada juga subyek hukum yang lain, yang tidak bersifat wajar atau mahluk, melainkan merupakan suatu organisasi. Organisasi yang memperoleh sifat subyek hukum, adalah badan hukum. Sebagai

20 Chidir Ali, 1999, Badan Hukum, Bandung : Alumni, hlm. 19-20. badan hukum ia dapat bertindak, ia boleh memiliki harta, boleh berunding, boleh mengikat perjanjian, boleh bertindak dalam persengketaan hukum dan sebagainya dan memikul tanggung jawab dalam arti hukum tentang segala perbuatannya". Pengaturan badan hukum di Indonesia tersebar dalam beberapa peraturan yang terpisah, baik dalam KUH Perdata (B.W.), KUH Dagang (Commercial Code) maupun dalam penetapan pemerintah sebagaimana yang diuraikan berikut ini.

\section{Perkumpulan (Pasal 1654-1665 KUH Perdata)}

Pasal 1654 KUH Perdata (B.W.) yang menegaskan eksistensi perkumpulan sebagai badan hukum : "Semua perkumpulan yang sah adalah, seperti halnya dengan orang-orang preman, berkuasa melakukan tindakan-tindakan perdata, dengan tidak mengurangi peraturan-peraturan umum, dalam mana kekuasaan itu telah diubah, dibatasi atau ditundukan pada acaraacara tertentu". Dalam pasal 1655 KUH Perdata (B.W.) diatur bahwa para pengurus dapat bertindak atas nama perkumpulan, mengikat perkumpulan kepada orang-orang pihak ketiga dan sebaliknya, begitu pula bertindak dimuka hakim, baik sebagai penggugat maupun sebagai tergugat. Pengaturan dalam KUH Perdata (BW) tersebut diperkuat juga dalam Stb. No. 64 1870 yang menegaskan tentang eksistensi rechtspersoonlijkheid van vereningingen kepribadian hukum dari perkumpulan yang mempunyai kedudukan sebagai subyek hukum.

Selaku badan hukum, maka pengurus perkumpulan harus memperhatikan penerapan doktrin ultra vires yaitu terhadap pembatasanpembatasan apa yang boleh dan apa yang tidak boleh dilakukan oleh pengurus dalam menjalankan kepengurusan mencapai tujuan perkumpulan tersebut. Batas-batas yang boleh dan tidak boleh dilakukan pengurus, dapat dilihat dalam Anggaran Dasar perkumpulan tersebut. Badan hukum perkumpulan pada umumnya bergerak dalam bidang sosial, sehingga diperlukan adanya transparansi, akuntabilitas dan keadilan dalam pengelolaan perkumpulan. Penyimpangan dan atau tindakan melampaui kewenangan (ultra vires) terhadap apa yang diatur dalam Ang- 
garan Dasar Perkumpulan (intra vires), akan membuka peluang pihak lain untuk menggugat pengurus perkumpulan baik secara perdata maupun pidana.

\section{Perseroan Terbatas (UU No. 40 Tahun 2007 tentang Perseroan Terbatas)}

Pasal 1 ayat (1) ditegaskan "Perseroan Terbatas, yang selanjutnya disebut perseroan, adalah badan hukum yang merupakan persekutuan modal, didirikan berdasarkan perjanjian, melakukan kegiatan usaha dengan modal dasar yang seluruhnya terbagi dalam saham dan memenuhi persyaratan yang ditetapkan dalam undang-undang ini serta peraturan pelaksanaannya". Pasal 7 ayat (4) UU No. 40/2007 ditegaskan bahwa: "Perseroan memperoleh status badan hukum pada tanggal diterbitkannya Keputusan Menteri mengenai pengesahan badan hukum Perseroan".

Diterapkannya doktrin ultra vires dalam Perseroan Terbatas dapat ditemukan dalam norma pengaturan dalam UU No. 40 Tahun 2007 tentang Perseroan Terbatas. Misalnya dalam Pasal 2 ditegaskan sebagai berikut: "Perseroan harus mempunyai maksud dan tujuan serta kegiatan usaha yang tidak bertentangan dengan ketentuan peraturan perundang-undangan, ketertiban umum dan/atau kesusilaan". Menurut Fred B.G. Tumbuan, pencantuman maksud dan tujuan Perseroan mempunyai dua segi, disatu pihak merupakan sumber kewenangan bertindak bagi perseroan, dan dilain pihak menjadi pembatasan dari ruang lingkup kewenangan bertindak Perseroan yang bersangkutan (de doelomschrijving van de rechtspersoon geltd als begrenzing van haar bevoegheid) ${ }^{21}$.

Selanjutnya dalam Pasal 15 ayat (1) diatur antara lain:

Anggaran Dasar sebagaimana dimaksud dalam Pasal 8 ayat (1) memuat sekurangkurangnya:

\footnotetext{
21 Fred B.G. Tumbuan, "Tugas dan Wewenang Organ Perseroan Terbatas Menurut Undang-Undang Tentang Perseroan Terbatas", PPH News Letter, No. 70, September 2007, hlm. 17.
}

(b) maksud dan tujuan serta kegiatan usaha perseroan;

(c) jangka waktu berdirinya perse-roan;

(d) besarnya jumlah modal dasar, modal ditempatkan dan modal dicetor;

(e) jumlah saham, klasifikasi saham apabila ada berikut jumlah saham untuk tiap klasifikasi, hak-hak yang melekat pada setiap saham, dan nilai nominal tiap saham;

(f) nama jabatan dan jumlah anggota direksi dan dewan komisaris;

(g) penetapan tempat dan tata cara penyelenggaran RUPS;

(h) tata cara pengangkatan, penggantian, pemberhentian anggota di-reksi dan dewan komisaris

(i) tata cara penggunaan laba dan pembagian dividen.

Norma pengaturan dalam Pasal 15 ayat 1 (b) yang menegaskan bahwa Anggaran Dasar Perseroan harus mencantumkan maksud dan tujuan serta kegiatan usaha Perseroan, menunjukkan bahwa doktrin ultra vires diterapkan secara ketat dalam hukum positif nasional khususnya terhadap badan hukum yang berbentuk Perseroan Terbatas (P.T.). Pengaturan secara ketat penerapan doktrin ultra vires lebih ditegaskan lagi dalam Pasal 19 dan Pasal 21 UU No. 40 Tahun 2007 yang mengatur bahwa perubahan Anggaran Dasar harus ditetapkan oleh RUPS dan disetujui oleh Menteri dalam hal perubahan Anggaran Dasar antara lain menyangkut maksud dan tujuan serta kegiatan usaha perseroan.

Pengaturan selanjutnya dalam Pasal 155 menegaskan: "Ketentuan dan tanggung jawab direksi dan/dewan komisaris atas kesalahan dan kelalaiannya yang diatur dalam undangundang ini tidak mengurangi ketentuan yang diatur dalam undang-undang Hukum Pidana". Dalam hubungan ini Erman Rajagukguk menegaskan bahwa tindakan-tindakan yang digolongkan sebagai ultra vires atau yang dianggap tidak berguna, tidak akan mendapat perlindungan hukum. ${ }^{22}$ Sedangkan Eddie Supriyadi menegaskan bahwa bila direksi melakukan tin-

22 Erman Rajagukguk, "Tanggung Jawab Direksi dan Business J udgement Rule", J urnal Hukum, Vol. 3. No. 1 Oktober 2008, hlm. 5. 
dakan-tindakan diluar tugas dan kewenangannya (ultra vires), maka tanggung jawab direksi adalah pribadi (penuh) ${ }^{23}$.

Pembahasan penerapan doktrin ultra vires secara ketat dalam hukum perseroan, menunjukan bahwa Indonesia mengambil sikap yang berbeda dalam pengaturan hukum perseroan, misalnya dibandingkan dengan Belanda, Australia, Inggris dan Amerika Serikat. Hal ini dapat dipahami karena pertimbangan bahwa pembangunan perekonomian nasional harus memiliki landasan yang kokoh yang perlu didukung oleh suatu undang-undang yang mengatur tentang perseroan terbatas guna menjamin terselenggaranya iklim usaha yang kondusif.

Doktrin ultra vires juga ternyata diterapkan secara ketat dalam UU No. 25 tahun 2003 tentang Tindak Pidana Pencucian Uang. Dalam Pasal 4 ayat (3) undang-undang tersebut diatur sebagai berikut:

“Korporasi tidak dapat diminta per-tanggung jawaban pidana terhadap suatu tindak pidana pencucian uang yang dilakukan oleh pengurus yang mengatasnamakan korporasi, apabila perbuatan tersebut dilakukan melalui kegiatan yang tidak termasuk dalam lingkup usahanya sebagaimana diten-tukan dalam anggaran dasar atau ketentuan lain yang berlaku bagi korporasi yang bersangkutan".

Berdasarkan ketentuan diatas maka dapat ditarik kesimpulan bahwa hanya perbuatan-perbuatan yang intra vires yang dilakukan oleh pengurus saja yang dapat dimintakan pertanggungjawaban pidana kepada korporasi yang bersangkutan, selain kepada pengurus yang melakukan perbuatan itu. Perbuatan ultra vires menjadi tanggung jawab pribadi pengurus dan tidak dapat dimintakan pertanggungjawaban pidana kepada korporasi. Pengaturan yang ketat terhadap perbuatan ultra vires terhadap badan hukum perseroan, maka dapat dipastikan bahwa pengaruh penerapan aturan tersebut terhadap badan hukum selain perseroan akan sangat kuat, mengingat aturan-aturan yang ba-

23 Eddie Supriyadi, "Tanggung Jawab Direksi", Jurnal Hukum Themis, Vol. 1 Nomor 1, Oktober 2006, hlm. 45. ru tersebut dapat dijadikan dasar dalam penegakan hukum jika muncul masalah-masalah berkaitan dengan pelanggaran doktrin ultra vires yang dilakukan oleh direksi ataupun pengurus badan hukum yang bersangkutan.

\section{Kerkgenootschappen/Persekutuan Gereja (S. 1927 No. 156 Regeling van de Rechtspositie der Kerk)}

Staatsblad 27-156 yang dikeluarkan meIalui Keputusan Ratu Belanda tanggal $29 \mathrm{~J}$ uni 1925 No. 80, Pemerintah Belanda mengatur kedudukan Persekutuan atau Perkumpulan Gereja sebagai berikut:

(1) Kerken of kergenooschappen, alsmede hunne zelfstandige onderdeelen, bezitten van rechtswege rechtspersoonlijkheid.

(2) Om als kerk of kerkgenootschap, dan wel als zelfstandig onderdeel daarvan, te worden aangemerkt, is eene daartoe strekkende verklaring vereischt van den Gouverneur - General.

Aturan tersebut diperkuat dengan dikeluarkannya Stb. 27 - 157 dan Stb. 27 - 532, yang pada pokoknya memberikan kedudukan Persekutuan Gereja atau Perkumpulan Gereja sebagai badan hukum dimana status badan hukum tersebut diperoleh setelah permohonan pengajuan sebagai badan hukum disetujui oleh Gubernur Jenderal Hindia Belanda. Aturan tersebut masih berlaku dalam hukum positif di Indonesia karena belum ada gantinya, namun pengesahan sebagai sebuah Perkumpulan atau Persekutuan Gereja sebagai badan hukum dilakukan oleh Departemen Agama RI, dalam hal ini Direktur Jenderal Bimas Kristen Protestan/ Khatolik.

Diakuinya Persekutuan Gereja sebagai badan hukum, maka para pengurus Gereja tersebut haruslah mempedomani apa yang diatur dalam Anggaran Dasar (AD) dan Anggaran Rumah Tangga (ART) yang berlaku ketika Anggaran Dasar dan Anggaran Rumah Tangga tersebut disahkan oleh Departemen Agama RI. Konflik yang terjadi pada beberapa Persekutuan Gereja, adalah karena pengurus melakukan tindakan melampaui kewenangan ultra vires seba- 
gaimana yang diatur dalam AD/ART Persekutuan Gereja (intra vires) yang dimakusud.

\section{Koperasi (UU No. 25 Tahun 1992 tentang Perkoperasian)}

Pasal 1 ayat (1) UU No. 25 Tahun 1992 tentang Perkoperasian mengatur bahwa bahwa: "Koperasi adalah badan usaha yang beranggotakan orang-seorang atau badan hukum Koperasi dengan melandaskan kegiatannya berdasarkan prinsip Koperasi sekaligus sebagai gerakan ekonomi rakyat yang berdasarkan atas asas kekeluargaan". Sementara dalam Pasal 9 UU No. 25 Tahun 1992 diatur bahwa: "Koperasi memperoleh status badan hukum setelah akta pendiriannya disahkan oleh pemerintah".

Pasal 7 UU No. 25 Tahun 1992 mengatur: "Pembentukan koperasi sebagaimana dimaksud dalam Pasal 6 dilakukan dengan akta pendirian yang memuat Anggaran Dasar", sedangkan dalam Pasal 8 diatur sebagai berikut:

Anggaran Dasar sebagaimana dimaksud dalam Pasal 7 ayat (1) memuat:
(a) daftar nama pendiri;
(b) nama dan tempat kedudukan;
(c) maksud dan tujuan serta bidang usaha;
(d) ketentuan mengenai keanggotaan;
(e) ketentuan mengenai rapat anggo-ta;
(f) ketentuan mengenai pengelolaan;
(g) Ketentuan mengenai permodalan;
(h) ketentuan mengenai jangka waktu berdirinya; (i) ketentuan mengenai pembagian si-sa
hasil usaha;
(j) ketentuan mengenai sanksi.

Ketentuan Pasal 7 (1) huruf b, tetap mensyaratkan pencantuman maksud dan tujuan serta bidang usaha. Deskripsi tentang apa yang harus dimuat dalam suatu Anggaran Dasar Koperasi mencerminkan penerapan doktrin ultra vires dalam pengelolaan koperasi. Kewenangan pengurus koperasi ditegaskan kembali dalam Pasal 24: "Pengurus berwenang melakukan tindakantindakan dan upaya-upaya bagi kepentingan dan kemanfaatan koperasi sesuai dengan tanggung jawabnya dan keputusan-keputusan rapat anggota". Kelalaian pengurus memenuhi tanggung jawabnya telah diatur dalam Pasal 25 UU
No. 25 Tahun 1992. Berdasarkan paparan tersebut, maka pengaturan Badan Hukum Koperasi dalam UU No. 25 Tahun 1992 tentang Perkoperasian, menerapkan doktrin ultra vires, dimana pengurus koperasi tidak boleh mengambil tindakan diluar kewenangan yang diamanatkan undang-undang ini.

\section{Yayasan (UU No. 16 Tahun 2001 tentang Yayasan jo. UU No. 28 Tahun 2004 tentang Perubahan Atas UU No. 16 Tahun 2001 tentang Yayasan)}

Pasal 1 ayat (1) UU No. 16 Tahun 2001 jo UU No. 28 Tahun 2004 tentang Perubahan UU No. 16 Tahun 2001 tentang Yayasan diatur sebagai berikut: "Yayasan adalah badan hukum yang terdiri atas kekayaan yang dipisahkan dan diperuntukan untuk mencapai tujuan tertentu dibidang sosial, keagamaan, dan kemanusiaan, yang tidak mempunyai anggota". Dalam Pasal 11 ayat (1) UU No 16 Tahun 2001 jo UU No. 28 Tahun 2004 tentang Perubahan UU No. 16 Tahun 2001, diatur sebagai berikut "Yayasan memperoleh status badan hukum setelah akte pendirian Yayasan sebagaimana dimaksud dalam Pasal 9 ayat (2) memperoleh pengesahan dari Menteri".

Konstruksi yuridis Yayasan sebagai badan hukum, disertai dengan pembatasan bahwa Yayasan hanya dapat bergerak dalam tiga bidang: sosial, keagamaan dan kemanusiaan. Sedangkan Akta pendirian yang memuat Anggaran Dasar sebagaimana diatur dalam Pasal 14 sekurangkurangnya memuat:

(1) nama dan tempat kedudukan;

(2) maksud dan tujuan serta kegiatan untuk mencapai maksud dan tujuan tersebut;

(3) jangka waktu pendirian;

(4) jumlah kekayaan awal yang dipisahkan dari kekayaan pribadi pendiri dalam bentuk uang atau benda;

(5) cara memperoleh dan penggunaan kekayaan;

(6) tata cara pengangkatan, pemberhentian, dan penggantian anggota Pembina, Pengurus, dan Pengawas;

(7) hak dan kewajiban anggota Pembina, Pe-ngurus dan Pengawas;

(8) tata cara penyelenggaraan rapat organ Yayasan; 
(9) ketentuan mengenai perubahan Anggaran Dasar;

(10)penggabungan dan pembubaran Yayasan;

(11)penggunaan kekayaan sisa likuidasi atau penyaluran kekayaan Yayasan setelah pembubaran.

Berdasarkan norma-norma pengaturan yang dimuat dalam Anggaran Dasar Yayasan maka jika organ Yayasan melakukan tindakan diluar apa yang diatur dalam Anggaran Dasar tersebut, maka perbuatan tersebut tergolong ultra vires dan organ Yayasan yang melakukan perbuatan tersebut diancam pidana penjara lima tahun sebagaimana diatur dalam Pasal 5, Pasal 53 dan Pasal 70 UU No.16 jo. UU No. 28 Tahun 2004 tentang Perubahan atas UU No. 16 Tahun 2001 tentang Yayasan. Menurut penelitian Margareth J oyce Karnadi banyak penafsiran berbeda berkaitan dengan yayasan yang telah didirikan baik sebelum maupun sesudah diberlakukannya UU No. 16 Tahun 2001 jo. UU No. 28 Tahun 2004. Namun yang pasti semua yayasan yang ada di Indonesia, wajib menyesuaikan anggaran dasarnya sesuai aturan perundangan yang berlaku ${ }^{24}$.

\section{Perusahaan Asuransi (Pasal 286 KUH Dagang)}

Pasal 286 KUH Dagang mengatur: “Perseroan-perseroan pertanggungan bertimbal balik diatur menurut perjanjian-perjanjian dan reglemen-reglemen yang bersangkutan, dan apabila itu tidak lengakap, menurut asas hukum pada umumnya". Masalah apakah perseroanperseroan pertanggungan bertimbal balik (wederkerige versekering-of waarborgmaatschappijen) atau perusahaan asuransi adalah badan hukum atau bukan, telah berakhir dengan meIalui arrest H.R. 20 Oktober 1865 W. 2736, yang menetapkan bahwa asuransi adalah "zadelijk Lichaam". Dalam Pasal 1654 KUH Perdata perusahaan asuransi tersebut berwenang melakukan perbuatan hukum (burgerlijke handeling) yang berarti bahwa perusahaan asuransi adalah badan hukum.

24 Margareth Joyce Karnadi, 2006, "Penataan Yayasan Menurut UU No. 16 Tahun 2001 jo. UU no. 28 Tahun 2004 tentang Yayasan", Jurnal Hukum Gloria Yuris, Vol. 6, No. 1J anuari - April 2006.
Dinamika yang pesat dalam perkembangan usaha auransi saat ini, telah mengakibatkan dikeluarkannya aturan-aturan ketat terhadap usaha perasuransian, antara lain dalam UU No. 2 Tahun 1992 tentang Usaha Perasuransian, PP. No. 73 Tahun 1992 tentang Penyelenggaraan Usaha Perasuransian, PP No. 63 Tahun 1999 tentang Perubahan Atas PP No. 73 Tahun 1992, Keputusan Menteri Keuangan No. 426/ KMK/ 2003 tentang Perizinan Usaha dan Kelembagaan Perusahaan Asuransi dan Perusahaan Reasuransi. Dalam aturan-aturan tersebut, bentuk badan hukum usaha perasuransian telah diatur: Perusahaan Perseroan (BUMN Persero yang berbentuk Perseroan Terbatas yang modal sahamnya terbagi dalam saham yang seluruh atau paling sedikit $51 \%$ sahamnya dimiliki oleh negara yang bertujuan mengejar keuntungan vide Pasal 1 ayat (2) UU No. 19 Tahun 2003 tentang BUMN), Koperasi, Perseroan Terbatas, dan Usaha Bersama. Dewasa ini perusahaan-perusahaan asuransi swasta (kecuali Persero) lebih suka memilih wadah badan hukum Perseroan Terbatas. Dengan memilih bentuk Perusahaan Asuransi sebagai Perseroan Terbatas, maka ketentuan-ketentuan dalam UU No. 40 Tahun 2007 ten-tang Perseroan Terbatas berlaku bagi Perusahaan Asuransi.

\section{Partai Politik (UU No. 2 Tahun 2008 tentang Partai Politik)}

Pasal 3 ayat (1) UU No. 2 Tahun 2008, diatur bahwa: "Partai politik harus didaftarkan ke Departemen untuk menjadi badan hukum". Syarat-syarat untuk diakui sebagai badan hukum, diatur dalam Pasal 3 ayat (2). Sedangkan Pasal 4 ayat (3) mengatur: "Pengesahan partai politik sebagai badan hukum dilakukan dengan Keputusan Menteri paling lama 15 (lima belas) hari sejak berakhirnya proses penelitian dan/ atau verifikasi".

Pengesahan Partai Politik menjadi badan hukum membawa konsekuensi pengurus Partai Politik tersebut wajib mempedomani aturan dalam Anggaran Dasar (AD) maupun Anggaran Rumah Tangga (ART) Partai Politik tersebut. Pemeriksaan yang dilakukan terhadap pengurus Partai Politik karena laporan yang diajukan baik 
dari anggota Partai Politik tersebut yang tidak puas melihat kinerja pengurus, maupun laporan pihak ketiga kepada yang berwajib karena penyimpangan yang dilakukan pengurus terhadap AD / ART Partai Politik tersebut jika ada dasar yang kuat bahwa perbuatan tersebut melampaui kewenangannya. Doktrin ultra vires dengan demikian berlaku bagi Partai Politik yang terdaftar dan berbadan hukum.

\section{Organisasi Notaris (Ikatan Notaris Indonesia - INI)}

Ikatan Notaris Indonesia (INI) secara resmi didirikan sejak tanggal 1 J uli 1908 berkedudukan di Jakarta diakui sebagai badan hukum berdasarkan Gouverments Besluit tanggal 5 September 1908 No. 9. Kedudukan sebagai badan hukum INI dipertegas lagi dalam Keputusan Menteri Hukum dan HAM RI No. AHU-03.AH. 01.07 Tahun 2009 tanggal 12 J anuari 2009 tentang Persetujuan Perubahan Anggaran Dasar Perkumpulan Ikatan Notaris Indonesia hasil Konggres XIX Ikatan Notaris Indonesia di J akarta, tanggal 27 - 28 J anuari 2006. Dalam kedududukannya sebagai Badan Hukum yang memiliki Anggaran Dasar, maka segala sesuatu yang dilakukan pengurus INI haruslah berpedoman pada aturan dalam Anggaran Dasar INI. Pelanggaran terhadap aturan tersebut adalah ultra vires dan dapat dimintakan pertanggung jawaban pidana maupun perdata tergantung dimensi dan akibat perbuatan tersebut.

Badan hukum pendidikan yang diatur dalam UU No. 9 Tahun 2009 tentang Badan Hukum Pendidikan tidak dibahas sebab UU No. 9 Tahun 2009 telah dinyatakan oleh Mahkamah Konstitusi dalam amar Putusan Nomor 11-14-21-126 dan 136/PPU-VII/ 209 bahwa UU No. 9 Tahun 2009 tidak memiliki keberlakuan karena substansinya bertentangan dengan konstitusi (inkonstitusional). Dikemudian hari oleh aturan perundang-undangan dan melalui penetapan pemerintah mungkin saja dikeluarkan aturan baru yang menyangkut pendirian badan hukum baru sesuai kebutuhan masyarakat. Suatu hal yang tidak dapat dihindari adalah kenyataan bahwa penerapan doktrin ultra vires secara ketat berlaku bagi setiap badan hukum yang ada di Indonesia.

\section{Prosedur Pendirian Badan Hukum}

Pendirian suatu badan hukum diawali dengan pembuatan Anggaran Dasar dan jika diperlukan, juga dilengkapi dengan Anggaran Rumah Tangga. Jika Anggaran Dasar mengatur eksistensi badan hukum dari perspektif eksternal, maka Anggaran Rumah Tangga melihat dari perspektif internal. Bahwa pendirian suatu badan hukum haruslah memenuhi syarat-syarat tertentu menurut ketentuan pendirian badan hukum terkait, sebagaimana yang diuraikan pada pembahasan sebelumnya. Anggaran Dasar tersebut harus dibuat dalam suatu akta otentik. Sedangkan pengertian suatu akte otentik diatur dalam Pasal 1868 KUH Perdata (B.W.): "Suatu akta otentik ialah suatu akta yang didalam bentuk yang ditentukan oleh undang-undang, dibuat oleh atau dihadapan pegawai-pegawai umum yang berkuasa untuk itu ditempat di mana akta dibuatnya". Dalam Pasal 1 ayat (1) Undang-undang No. 30 Tahun 2004 tentang J abatan Notaris diatur sebagai berikut: "Notaris adalah pejabat umum yang berwenang untuk membuat akta otentik dan kewenangan lainnya sebagaimana dimaksud dalam undang-undang ini". Sedangkan dalam Pasal 1 ayat (7) UU No. 30 tahun 2004 ditegaskan bahwa: "Akta notaris adalah akta otentik yang dibuat oleh atau di hadapan notaris menurut bentuk dan tata cara yang ditetap-kan undang-undang ini".

Akte pendirian badan hukum dalam kepustakaan common law disebut memorandum of associations atau juga by laws, charter maupun letter of incorporation. Di Indonesia yang dimaksud memorandum of association adalah Anggaran Dasar yang dibuat dihadap notaris. Anggaran Dasar tersebut merinci tuj uan didirikannya badan hukum tersebut, serta apa saja yang boleh dilakukan oleh direksi atau pengurus badan hukum tersebut. Perbuatan yang dilakukan melampaui kewenangan (ultra vires) yang diatur dalam Anggaran Dasar dan Anggaran Rumah Tangga (intra vires) memiliki konsekuensi baik perdata maupun pidana. 
Penutup

Simpulan

Penerapan doktrin ultra vires pada negara-negara common law mulai sangat dibatasi hanya pada internal perusahaan saja, dan diutamakan penerapannya untuk melindungi para pemegang saham dan investor. Pembatasan ketat penerapan doktrin ultra vires dalam proses peradilan tidak dilakukan begitu saja, tetapi dengan menggunakan doktrin lain sebagai pengganti seperti doktrin estoppels, unjust enrichment, quasi contract dan waiver yang lebih mencerminkan keadilan.

Penerapan doktrin ultra vires dalam hukum perseroan, di Indonesia, dilakukan secara ketat, yaitu dalam rangka membangun suatu struktur perseroan yang sehat guna menjamin terselenggaranya iklim usaha yang kondusif. Penerapan doktrin ultra vires di Indonesia lebih cenderung dikaitkan dengan suatu tindak pidana yang dilakukan oleh direksi atau pengurus, yang dibuat melampaui atau diluar kewenangan yang ditetapkan dalam Anggaran Dasar perseroan. Bahwa perbuatan-perbuatan dalam lingkup intra vires yang dilakukan oleh pengurus saja yang dapat dimintakan pertanggungjawaban pidana kepada korporasi yang bersangkutan, selain juga kepada pengurus yang melakukan perbuatan itu. Sedangkan perbuatan ultra vires hanya dapat dipertanggung jawabkan kepada pribadi pengurus dan tidak dapat dipertanggungjawab-kan kepada korporasi.

Anggaran Dasar yang mengatur dan menetapkan tujuan dan maksud perseroan harus memuat cakupan bidang usaha yang seluasluasnya yang secara prediktif merupakan bidang-bidang yang ada saling keterkaitan antara sesamanya, sehingga dalam hal perseroan melakukan ekspansi usaha, tidak perlu melakukan perubahan Anggaran Dasar, minimal pada maksud dan tujuan pendirian perseroan, sehingga gugatan atas dasar penerapan doktrin ultra vires ruangnya dapat dipersempit. Hal tersebut perlu diperhatikan dalam pendirian perseroan untuk mencegah perseroan digugat atas dasar doktrin ultra vires

\section{Saran}

Berkaitan dengan penerapan doktrin ultra vires dalam hukum positif nasional, maka terhadap badan hukum lain selain Perseroan Terbatas, pengurus harus menyikapinya dengan mengevaluasi kembali Anggaran Dasar pendirian badan hukum tersebut (Yayasan, Koperasi, Perasuransian, Persekutuan Gereja dan lainlain), apakah telah memadai atau memerlukan perubahan yang membutuhkan persetujuan Menteri Hukum dan HAM. Perubahan tersebut dalam rangka untuk mencegah munculnya gugatan yang didasarkan pada doktrin ultra vires baik terhadap badan hukum, maupun terhadap pengurus-pengurusnya.

\section{Daftar Pustaka}

Ali, Chidir. 1999. Badan Hukum. Bandung: Alumni;

Ard, J osh. "Preparing Law Student to Recognize the Unauthorized Practice of Law". Michigan Bar J ournal, J une 2002;

Black, Henry Campbell. 1990. Black's Law Dictionary. St. Paul, Minn., Sixth Edition, West Publishing Co.;

Carpenter, Charles E. "Should the Doctrine of Ultra Vires Be Discarded?". The Yale Law J ournal, Vol. 33, No. 1 (Nov., 1923), tersedia di website http:// www. jstor. org/pss/ 788458 diakses taggal 22 Mei 2011;

Cheeseman, Henry R. 2001. Business Law. New Yersey: Prentice Hall, Upper Saddle River;

Craig, Paul. "The EJ C and Ultra Vires Action : A Conceptual Analysis". Common Market Law Review, No. 48, Tahun 2011;

Endicott, Timothy. "Constitutional Logic". University of Toronto Law Journal, No. 53, Tahun 2003;

Ewing, K.D. "Company Political Donations and the Ultra Vires Rule"; Modern Law Review, Vol. 47, J an. 1984;

Griffin, Stephen. 1998. "The Rise and Fall of the Ultra Vires Rule in Corporate Law". Mountbatten Journal of Legal Studies, J une 1998, tersedia diwebsite http:// ssudl. solent.ac.uk/ policies/954/ diakses tanggal 23 Mei 2011; 
Hamilton, Robert W. 2005. Cases and Materials on Corporations. St. Paul. Minn., American Case Book Series, West Group;

Jenkins, David. "From Unwritten to Written: Transfor-mation in the British Common Law Constitution". Vanderbilt J ournal of Transnational Law, Vol. 36, Tahun 2003;

J oseph, Philip A. "The Demise of ultra vires - a reply to Christoper Forsyth and Linda Whittle". Canterbury Law Review 10, tersedia di website http:// NZLII/ Databases/canterbury law review/2002/ Canter-Law Rw 10, diakses tanggal 22 Mei 2011;

Karnadi, Margareth J oyce. 2006. "Penataan Yayasan Menurut UU No. 16 Tahun 2001 jo. UU no. 28 Tahun 2004 tentang Yayasan". Jurnal Hukum Gloria Yuris, Vol. 6, No. 1 J anuari - April 2006;

Lipton, Daniel. "Corporate Capacity for Crime and Politics: Defining Corporate Personhood at the Turn of the Twentieth Century". Virginia Law Review Vol. 96, Tahun 2010;

Mack, Frank A. "The Law on Ultra Vires Acts and Contracts of Private Corporations". Marquette Law Review, tersedia di website http://epublications. marquette. edu/ cgi/ viewcontent. cgiarticle $=4163$ diak ses tanggal 23 Mei 2011;

Mahlmann, Matthias. "The Politics of Constitutional Identity and its Legal Frame - the Ultra Vires Decision of the German Federal Constitution". German Law J ournal, Vol. 11 No. 12, Tahun 2010;

Mitchell, Gregory and Richard Brent. "English Law Contracts, Foreign Counterparties and Ultra Vires". Butterworths Journal of International Banking and Financial Law, September 2010;

Omar, Paul J. "Purposes and Objects: The Protracted Demise of the Ultra Vires Rule". Bond Law Review Vol. 16, Issue 1, Tahun 2004, tersedia di website http:// epublications. bond. edu. au/ b/r/ vol16/ iss1/ 4, diakses tanggal 22 Mei 2011;

Raghuvanshi, Raghvendra Singh. 2009. Doctrin of Ultra Vires in Company Law. National Law Institute University, Bhopal, India. Diakses pada website http://apjlsg. com/article-aspx?c6b62 diakses tanggal 20 Februari 2011;

Rajagukguk, Erman. “Tanggung J awab Direksi dan Business J udgement Rule". Jurnal Hukum, Vol. 3. No. 1 Oktober 2008;

Supriyadi, Eddie. "Tanggung Jawab Direksi". Jurnal Hukum Themis, Vol. 1 Nomor 1, Oktober 2006;

Tumbuan, Fred B.G. "Tugas dan Wewenang Organ Perseroan Terbatas Menurut Undang-Undang Tentang Perseroan Terbatas". PPH News Letter, No. 70, September 2007. 